De Jure: Jurnal Hukum dan Syari'ah

Vol. 12, No. 2, Desember 2020, h. 279-296

ISSN (Print): 2085-1618, ISSN (Online): 2528-1658

DOI: http://dx.doi.org/10.18860/j-fsh.v12i2.10437

Available online at http://ejournal.uin-malang.ac.id/index.php/syariah

\title{
Tanggung Jawab Hukum Pelaku Usaha Parkir Terhadap Kehilangan Barang Konsumen Dalam Kendaraan \\ Legal Responsibilities of Parking Business Actors Against Loss of Consumer Goods in Vehicles
}

\begin{abstract}
:
Parking area is a type of strategic business needed by the community. however, one obstacle that often arises is security disturbances such as loss of consumer goods in vehicles. It is not uncommon for parking land owners to be reluctant to take responsibility for this loss. The purpose of this study was to describe the legal relationship between parking managers and consumers and to analyze the responsibilities of parking managers in the event of loss of goods in the vehicle. This article is based on doctrinal law research with statutory regulations approach and conceptual approach. The results of this study indicate that the legal relationship between the parking manager and the owner's consumer is an agreement for storing goods, not renting land. The legal consequence of the goods storage agreement in the parking agreement is to impose responsibility on the parking manager for the loss of the vehicle and the items in the vehicle.
\end{abstract}

Keywords: parking area; agreement; legal responsibility

Abstrak:

Lahan parkir merupakan jenis usaha strategis yang dibutuhkan oleh masyarakat. namun, salah satu kendala yang sering muncul adalah gangguan keamanan seperti hilangnya barang konsumen di kendaraan. Tidak jarang pemilik lahan parkir enggan bertanggung jawab terhadap kehilangan tersebut. Tujuan penelitian ini adalah untuk mendeskripsikan hubungan hukum pengelola parkir dengan konsumen dan menganalisis tanggung jawab pengelola parkir dalam hal terjadinya kehilangan barang di dalam kendaraan. Artikel ini berdasarkan penelitian hukum doctrinal dengan pendekaran peraturan perundang undangan dan pendekatan konsep. Hasil dari penelitian ini menunjukkan bahwa hubungan hukum antara pengelola parkir dengan konsumen pemilik adalah perjanjian penitipan barang, bukan sewa-menyewa lahan. Konsekuensi hukum dari perjanjian penitipan barang dalam perjanjian parkir adalah membebankan tanggung jawab kepada pengelola parkir terhadap kehilangan kendaraan beserta barang yang terdapat di dalam kendaraan.

Kata Kunci : lahan parkir; perjanjian; tanggung jawab hukum. 
280 | De Jure: Jurnal Hukum dan Syar'iah, Vol. 12 No. 2 Tahun 2020

\section{Pendahuluan}

Secara umum di daerah-daerah di seluruh Indonesia, bisnis parkir merupakan bisnis yang cukup menjanjikan bahkan bisa menjadi salah satu sumber strategis Pendapatan Asli Daerah (PAD). Hal ini bisa dilihat banyak daerah-daerah yang membuat Peraturan Daerah yang mengatur tentang parkir. Potensi bisnis parkir memang luar biasa jika dikelola dengan baik, sebaliknya jika tidak maka ini dapat menjadi potensi konflik antara pemerintah dengan pelaku usaha dan antara konsumen dengan pelaku usaha parkir. Oleh karenanya pelaku usaha tidak diperkenankan dalam menjalankan usahanya hanya mengejar profit semata, tanpa melaksanakan tanggung jawab yang melekat padanya sebagai pelaku usaha.

Dalam bisnis parkir yang masih menyisakan persoalan hukum dan menjadi perdebatan adalah terkait hubungan hukum antara pelaku usaha dengan konsumen parkir. Di beberapa daerah seperti Provinsi DKI Jakarta, Kota Denpasar, Kota Mataram dan beberapa daerah yang lain mengatur bahwa pelaku usaha dibebaskan dari tanggung jawab apabila terjadi kehilangan kendaraan yang diparkir, selain itu juga ada yang mengatur tanggung jawab pelaku usaha parkir yaitu dengan cara ganti rugi hanya setengah dari nilai kendaraan yang hilang. Dengan beberapa substansi peraturan daerah yang mengatur tanggung jawab pelaku usaha tersebut tentu mengundang tanda tanya besar, sehingga memang apakah dibenarkan tanggung jawab pelaku suaha parkir yang seperti demikian dalam perjanjian parkir.

Berbicara hubungan hukum antara pelaku usaha dengan konsumen tentu harus mengacu pada pada dua aturan utama yaitu KUHPerdata dan UndangUndang No.8 Tahun 1999 tentang Perlindungan Konsumen. Dalam menjalankan usahanya, pelaku usaha harus memiliki perspektif perlindungan konsumen. Apalagi dengan dunia yang sudah tanpa batas ini (borderless) manusia dalam memenuhi kebutuhan hidupnya tidak lepas dari posisi konsumen, meskipun dia adalah seorang produsen besar tetap saja posisi ini secara sirkuler bergantian. Oleh karena itu, hubungan antara pelaku usaha dengan konsumen harus diberikan regulasi, sehingga bisa menjadi pedoman dalam bertindak selaku pelaku usaha dan selaku konsumen dalam menjalankan hak dan kewajibannya masing-masing. ${ }^{1}$

Secara teoritik konsep proteksi terhadap konsumen seperti yang tercantum dalam Pasal 3 Undang-Undang Nomor 8 Tahun 1999 tentang Perlindungan Konsumen adalah mempunyai visi untuk mewujudkan masyarakat madani (civil society) yang kuat yaitu dalam rangka mewujudkan masyarakat adil dan makmur yang merata, baik secara materi maupun sepiritual dalam era ekonomi yang berdemokrasi berdasarkan Pancasila dan Undang-Undang Dasar 1945. Untuk melaksanakan itu semua, peran negara untuk mengatur mekanisme pasar sangat diperlukan karena hanya dengan berfungsinya mekanisme pasar yang sehat kegiatan perekonomian dalam masyarakat dapat meningkatkan kesejahteraan bagi orang-orang yang terdapat di dalamnya. Mekanisme pasar yang tepat harus diselenggarakan dengan menggunakan sistem apa yang disebut oleh Jimly Asshidiqie sebagai trias politika baru, di mana negara sebagai pembuat regulasi dan masyarakat harus berperan dalam menyalurkan aspirasi yang berdaulat, memberi

\footnotetext{
${ }^{1}$ Ahmad Zuhairi, Konstruksi Perlindungan Hukum Bagi Pengadu/Pelapor Kerugian Konsumen Dari Tuntutan Pencemaran Nama Baik, Jurnal Ius Kajian Hukum dan Keadilan, 3 no.1: 55, http://dx.doi.org/10.12345/ius.v3i7.199
} 
arah bagi penyelenggaraan negara, dan mengontrol jalannya pemerintahan secara partisipatoris serta pasar sebagai perantara kebutuhan hidup masyarakat dari produsen ke konsumen. Jika mekanisme check and balances ini tidak berjalan dengan baik maka akan melahirkan ketidak seimbangan yaitu pemerintah yang terlalu kuat akan melahirkan diktatorian, jika masyarakat terlalu kuat akan melahirkan anarkisme, dan jika pasar terlalu kuat akan melahirkan corpocracy (negara yang dikuasai oleh pemodal). ${ }^{2}$

Menimbang bahwa bisnis yang adil tidak akan terwujud tiba-tiba dengan sendirinya tanpa adanya intervensi pemerintah, kesadaran dunia usaha, dan peran aktif dari konsumen. Oleh karena itu regulasi yang seimbang perlu dikembangkan. ${ }^{3}$ Wujud untuk mengatur keseimbangan tersebut dalam Undang-Undang No. 8 Tahun 1999 tentang Perlindungan Konsumen mengatur tentang hak dan kewajiban pelaku usaha dan konsumen sehingga tercipta mekanisme pasar yang sehat. Salah satu hak konsumen yang diatur adalah hak atas keamanan dan kenyamanan (the right to be safety) atas barang dan jasa yang dikonsumsi. Jika hak tersebut dilanggar oleh pelaku usaha, maka konsumen bisa menggunakan haknya untuk menuntut pelaku usaha, baik secara perdata maupun pidana, dengan menggunakan undangundang perlindungan konsumen.

Dalam konteks perparkiran, jika tadi masih terdapat sisa masalah dan masih terdapat perbedaan pemahaman tanggung jawab pelaku usaha parkir jika terdapat kehilangan kendaraan konsumen, bagaimana dengan barang konsumen yang terdapat dalam kendaraan. Seperti salah satu kasus yang menarik dan menjadi perhatian ahli hukum yaitu kasus yang terjadi pada Tanggal 7 Juni 2017 yaitu kasus kehilangan uang yang terdapat dalam kendaraan mobil yang di Parkir oleh konsumen di lahan parkir Mataram Mall, Kota Mataram, Nusa Tenggara Barat. Kendaraan dengan nomor plat DR 77 MD milik Lalu Daryadi yang berasal dari Sekotong Lombok Barat. Kendaraan yang diparkir pada jam 15.30 kemudian ditinggal berbelanja. Sekembalinya ternyata kaca mobilnya sudah dipecah dan diambil uangnya oleh pencuri senilai Rp. 265.000.000,00,- (Dua Ratus Enam Puluh Lima Juta Rupiah). ${ }^{4}$

Praktik di lapangan bahwa pelaku usaha sering mengalihkan tanggung jawabnya terhadap konsumen parkir, dengan membuat pernyataan dalam spanduk atau perjanjian sepihaknya di dalam karcis yang mengatakan "kehilangan bukan tanggung jawab kami". Klausula baku yang berisikan pengalihan tanggung jawab atau menghindarkan diri untuk membayar ganti rugi seluruh atau sebagian baik karena wanprestasi atau perbuatan melawan hukum disebut juga klusa eksonarasi (exoneration clause). ${ }^{5}$

Lalu pertanyaannya, siapa yang bertanggung jawab terhadap hubungan hukum yang terjadi antara pelaku usaha parkir dan pemberi parkir. Untuk memperoleh jawaban tersebut, kiranya perlu dituntaskan dulu apa hubungan

\footnotetext{
2 Jimly Asshidiqi, Konstitusi Ekonomi (Jakarta: Kompas, 2010), 374.

${ }^{3}$ Johanes Widijantoro, Mewujudkan Perniagaan Berkeadilan Melalui Peningkatan Keadilan Konsumen, Jurnal Mimbar Hukum, 28 (3), 440, https://doi.org/10.22146/jmh.16672

${ }^{4} \mathrm{http}$ ://www.suarantb.com/news/2017/06/08/239984/Mobil.Mamiq.Dar,Tokoh.Berpengaruh.As al.Sekotong.Dibobol,Ratusan.Juta.Digondol. Diakses tanggal 26 Februari 2018.

${ }^{5}$ Ida Bagus Prakosa et all, Perlindungan Hukum Terhadap Konsumen Jasa Parkir Dalam Hal Terjadinya Kehilangan Helm dan Kendaraan Bermotor Di Pasar Kreneng Denpasar, Jurnal Komunitas Yustisia, 3 (1), 2
} 
hukum antara pelaku usaha penyelenggara parkir dan konsumen parkir, apakah hubungan para pihak tersebut adalah perjanjian penitipan barang atau hanya sekedar perjanjian sewa lahan. Penulis melihat, karena belum jelasnya hubungan hukum inilah yang berimplikasi pada tidak jelasnya tanggung jawab pelaku usaha. Fokus tulisan ini yaitu mengkaji tentang hubungan hukum antara pelaku usaha Parkir dengan Konsumen Pemilik Kendaraan dan sejauh mana tanggung jawab pelaku usaha parkir terhadap barang yang terdapat di dalam kendaraan Konsumen. Jenis penelitian yang digunakan dalam tulisan ini adalah penelitian hukum normatif atau disebut juga dengan penelitian hukum doktrinal yaitu penelitian yang membahas doktrin-doktrin atau asas-asas dalam ilmu hukum, ${ }^{6}$ khusus yang terkait dengan permasalah yang akan diteliti, dengan menggunamkan bahan kepustakaan atau data sekunder yang meliputi buku-buku serta ketentuanketentuan hukum yang terdapat pada peraturan perundang-undangan, asas-asas hukum, kaedah hukum dan sistematika hukum serta mengkaji ketentuan perundang-undangan, putusan pengadilan dan bahan hukum lainnya. ${ }^{7}$

\section{Hasil dan Pembahasan \\ Hubungan Hukum Antara Pelaku Usaha Parkir dengan Konsumen Pemilik Kendaraan}

Untuk mengetahui tanggung jawab pelaku usaha terhadap kendaraan atau barang yang ada dalam kendaraan konsumen perlu diketahui terlebih dahulu hubungan hukum antara pelaku usaha parkir dengan konsumen pemilik kendaraan. Dalam perjanjian parkir terdapat dua pemahaman di dalam masyarakat antara lain yaitu, pemahaman pertama yang mengakui bahwa perjanjian parkir itu adalah perjanjian sewa lahan, artinya pemilik lahan hanya menyewakan lahan kepada pemilik kendaraan parkir. Dalam hal ini pelaku usaha atau pengelola parkir tidak bertanggung jawab terkait dengan kehilangan kendaraan dari konsumen. Pemahaman ini secara implisit sudah dibuat dalam beberapa perda seperti Peraturan Daerah Khusus Ibu Kota Jakarta Nomor 5 Tahun 1999 tentang Perparkiran. Dalam Pasal 36 ayat (2) dikatakan bahwa;

"Atas hilangnya kendaraan dan/atau barang yang berada di dalam kendaraan selama berada di petak parkir, merupakan tanggung jawab pemakai tempat parkir".

Melihat klausul Pasal dalam Perda DKI Jakarta tersebut terlihat bahwa perjanjian parkir dalam Perda tersebut adalah perjanjian sewa lahan karena Perusahaan yang mengelola parkir dibebaskan dari tanggung jawab terhadap barang yang berada di atas obyek sewa. Justeru tanggung jawab kehilangan barang atau kendaraan dibebankan kepada konsumen. Hampir sama dengan Peraturan Daerah Kota Mataram No. 7 Tahun 2015 tentang Pengelolaan Parkir. Dalam Bab VI, Pasal 13 ayat (1) mengatakan bahwa:

"Segala kerusakan, kehilangan komponen kendaraan dan/atau kehilangan kendaraan selama kendaraan tersebut diparkir menjadi tanggung jawab

\footnotetext{
6 Johni Ibrahim, Teori dan Metode Penelitian Hukum Normatif (Malang: Bayu Media Publishing, 2005), 336.

${ }^{7}$ Zunnuraeni et all, Kewenangan Desa Dalam Pengelolaan Hutan Untuk Mitigasi Perubahan Iklim, Jurnal Ius Kajian Hukum dan Keadilan, 6 (1), 37. http://dx.doi.org/10.29303/ius.v6i1.524
} 
bersama antara orang/badan yang mengelola tempat parkir atau petugas/juru parkir dengan pemilik kendaraan bermotor."

Ayat (2) dikatakan bahwa;

"Tanggung jawab oleh orang/badan yang mengelola tempat parkir atau petugas/juru parkir sebagaimana dimaksud pada ayat (1), berupa ganti rugi paling banyak sebesar 50\% (lima puluh persen) dari nilai jual kendaraan yang hilang."

Hal ini memperlihatkan bahwa terjadinya dualisme pemahaman dalam hal tanggung jawab pelaku usaha dengan konsumen pemilik kendaraan berakibat pada terjadinya kekaburan (unclear norm) hubungan hukum antara pengelola parkir dan konsumen parkir. Akibat dari ketidak jelasan tersebut berimplikasi terhadap ketidak jelasan bentuk tanggung jawab pelaku usaha atau pengelola parkir. Ada yang membebankan tanggung jawab kepada konsumen, seperti yang terdapat dalam Perda DKI Jakarta No. 5 Tahun 1999, ada juga yang membebankan kedua belah pihak, yaitu pengelola parkir dan konsumen pemilik kendaraan. Model tanggung jawab ini dalam prakteknya banyak ditiru dalam perjanjian parkir yang berupa karcis di mana tertulis klausula eksonarasi yang menyatakan "kehilangan dan kerusakan kendaraan bukan tanggung jawab kami".

Tentu kehadiran klausula tersebut sangat merugikan konsumen, dan sebaliknya sangat menguntungkan pelaku usaha atau pengelola parkir, di mana pelaku usaha mempunyai bisnis yang menjanjikan keuntungan tanpa adanya risiko. Tentu hal ini bertentangan dengan prinsip keadilan. Meskipun di sisi lain, harus diakui juga bahwa kehadiran klausula baku dapat membantu kelancaran dalam perdagangan. Sulit juga membayangkan jika perjanjian dalam jumlah banyak dan kontrak sehari-hari setiap pihak harus menegosiasikan syarat dan ketentuannya. Misalnya dalam ketentuan tiket parkir, antara pelaku usaha dan konsumen tidak mungkin harus menegosiasikan lebih dahulu hak dan kewajiban masing-masing pihak dan akibat hukum terjadi apabila terjadi wanprestasi atau perbuatan melawan hukum. Namun dalam UUPK telah melarang beberapa jenis klausula baku untuk memberikan perlindungan hukum terhadap konsumen. ${ }^{8}$

Perjanjian sewa lahan dalam perjanjian perparkiran pada hakikatnya adalah perjanjian sewa-menyewa yang diatur dalam KUHPerdata. Perjanjian sewamenyewa adalah sebuah perjanjian di mana salah satu pihak mengikatkan dirinya untuk memberikan kepada pihak yang lainnya kenikmatan dari sesuatu barang, selama suatu waktu tertentu dan dengan pembayaran suatu harga yang oleh pihak yang tersebut terakhir itu disanggupi pembayarannya. Pengertian tersebut diatur dalam ketentuan Pasal 1548 KUHPerdata. ${ }^{9}$ Perjanjian sewa-menyewa, menurut Subekti, merupakan perjanjian seperti jual-beli atau perjanjian pada umumnya, yaitu perjanjian konsensual. Artinya dia sudah sah dan mengikat pada detik tercapainya kesepakatan terhadap unsur-unsur pokoknya, yaitu barang dan harga. Akan tetapi letak perbedaan perjanjian sewa-menyewa yiatu di mana hanya dapat memanfaatkan atau menggunakannya saja untuk dalam jangka waktu tertentu

8 Deviana Yuanitasari dan Hazar Kusmayanti, Eksistensi BPSK (Badan Penyelesaian Sengketa Konsumen) Dalam Pengawasan Pencantuman Klausula Baku Dalam Sistem Hukum Perlindungan Konsumen Indonesia, Jurnal IUS Kajian Hukum dan Keadilan, 7 (3), 427, http://dx.doi.org/10.29303/ius.v7i3.676

${ }^{9}$ Subekti, Aneka Perjanjian (Bandung, PT. Citra Aditya Bakti, 2014), 39. 
sesuai dengan kesepatakan para pihak. Oleh karena itu, bisa dikatakan bahwa penyewa hanya punya hak pakai dalam waktu tertentu dan tidak mendapatkan hak milik atas barang tersebut. ${ }^{10}$ Peraturan mengenai sewa-menyewa yang diatur dalam bab ketujuh Buku III B.W, berlaku untuk segala macam sewa-menyewa, mengenai semua jenis barang, baik bergerak maupun tidak bergerak, baik yang memakai waktu tertentu maupun tidak memakai waktu tertentu, karena waktu tertentu bukan menjadi syarat mutlak untuk perjanjian sewa-menyewa. ${ }^{11}$

Kewajiban pihak yang menyewakan berdasarkan Pasal 1550 KUHPerdata, adalah: (1) Menyerahkan barang yang disewakan kepada si penyewa; (2) Memelihara barang yang disewakan sedemikian hingga itu dapat dipakai untuk keperluan yang dimaksudkan; (3) Memberikan kepada si penyewa kenikmatan tenteram dari barang yang disewakan selama berlangsungnya persewaan. Kewajiban seperti yang disebutkan dalam point 3 (tiga) yaitu memberikan kenikamatan tenteram kepada si penyewa, menurut Subekti, yaitu kewajiban dari si pihak yang menyewakan untuk menanggulangi atau menangkis tuntutan-tuntutan hukum dari pihak ketiga. Kewajiban tersebut tidak mencakup gangguan-gangguan fisik, miasalnya orang-orang melempari rumahnya dengan batu atau tetangga membuang sampah di pekarangan rumah yang disewa. Hal tersebut ditegaskan dalam Pasal 1556 yang berbunyi:

"Pihak yang menyewakan tidaklah diwajibkan menjamin si penyewa terhadap rintangan-rintangan dalam kenikamatannya yang dilakukan oleh orang-orang pihak ketiga dengan peristiwa-peristiwa tanpa memajukan sesuatu hak atas barang yang disewa, dengan tidak mengurangi hak si penyewa untuk menuntut sendiri orang itu. Gangguan dari peristiwaperistiwa itu harus ditanggulangi sendiri penyewa".

Jika dilihat dari sudut kewajiban yang menyewakan, ketika diterapkan dalam konteks perjanjian parkir, maka perjanjian sewa menjadi tidak tepat. Hal ini dikarenakan dalam penerapan perjanjian parkir, pihak pengelola parkir (dalam konsep sewa lahan parkir bertindak sebagai pihak yang menyewakan) melakukan pengamanan lahan parkir miliknya yang telah disewa konsumen (dalam konsep sewa lahan parkir bertindak sebagai penyewa). Jika memang murni memakai konsep perjanjian perjanjian sewa lahan parkir (sewa-menyewa) maka seharusnya pihak yang menyewakan dibebaskan dari jaminan untuk menjaga objek sewa. Oleh karena itu, sebenarnya dalam praktek pihak yang menyewakan secara tidak langsung mengakui bahwa perjanjian parkir bukanlah perjanjian sewa lahan (sewamenyewa) seperti yang biasa didalilkan oleh pihak pengelola parkir. ${ }^{12}$

Kewajiban bagi si penyewa sebagaimana disebutkan dalam Pasal 1560 KUHPerdata ialah: (1) Memakai barang yang disewa sebagai bapak rumah yang baik, sesuai dengan tujuan yang diberikan kepada barang itu menurut perjanjian sewanya, atau jika tidak ada suatu perjanjian mengenai itu, menurut tujuan yang

\footnotetext{
${ }^{10}$ Paulus Tomy Prihwaskito, Tinjauan Yuridis Perjanjian Sewa Menyewa Depo Container Yard PT. Kawasan Barikat Nusantara Persero (Studi Kasus Putusan MA No. 116/PK/Pdt/2015, Diponegoro Law Journal, 5 (4), 4.

${ }^{11} \mathrm{Ibid}, 41$.

${ }^{12}$ Renaldo Oktavia Gardivega, Keberlakuan Perjanjian Penitipan Sebagai Perjanjian Sah Dalam Kegiatan Penyelenggaran Parkir Dikaitkan Dengan Asas Perbuatan Melawan Hukum Oleh Pengelola Parkir, Skripsi Fakultas Hukum Universitas Indonesia, 2011, 30-31
} 
dipersangkakan berhubung dengan keadaan; (2) Untuk membayar harga sewa pada waktu-waktu yang telah ditentukan. Jika melihat kewajiban pihak penyewa sebagai "bapak rumah tangga yang baik" artinya dia harus menggunakan barang yang disewa itu seakan-akan kepunyaannya sendiri. Selain itu, dia tidak diperbolehkan menggunakan barang yang disewa selain daripada yang menjadi tujuannya, atau untuk keperluan lain yang dapat merugikan pihak yang memberi sewa, maka pihak yang menyewakan dapat meminta pembatalan sewanya. Misalnya menyewa rumah tempat tinggal, tapi ternyata dalam realisasinya dipakai untuk perbengkelan atau perusahaan. ${ }^{13}$

Jika dilihat dalam konteks perparkiran, maka sesungguhnya perjanjian sewa lahan dalam perjanjian parkir adalah perjanjian sepihak. Perjanjian sepihak adalah perjanjian yang melahirkan kewajiban pada satu pihak dan hak kepada pihak lain. Padahal secara konseptual perjanjian sewa-menyewa adalah perjanjian yang melahirkan hak dan kewajiban bagi para pihak. Oleh karena terdapat klausula baku yang menyatakan pengelola parkir tidak bertanggung jawab atas apapun, artinya maka tidak ada kewajiban apapun terhadap pemberi sewa, yang ada hanya kewajiban si penyewa untuk membayar sejumlah uang sewa kepada pemberi sewa, dan hak pemberi sewa untuk menerima uang sewa. ${ }^{14}$ Sehingga menerapkan perjanjian sewa lahan (sewa-menyewa) dalam perjanjian parkir adalah hal yang tidak tepat secara konseptual.

Dalam pengertiannya, risiko adalah suatu obligasi atau kewajiban untuk menanggung kerugian yang disebabkan oleh suatu perisitiwa yang terjadi di luar kesalahan salah satu pihak, yang menimpa barang yang menjadi obyek perjanjian. ${ }^{15}$ Risiko dalam perjanjian sewa-menyewa secara jelas telah diatur dalam Pasal 1553 yang menyatakan bahwa: "Jika selama waktu sewa, barang yang disewakan sama sekali musnah karena suatu kejadian yang tak disengaja, maka perjanjian sewa gugur demi hukum". "Gugur demi hukum" artinya para pihak tidak dapat menuntut suatu apapun dari pihak lawannya, hal mana berarti bahwa kerugian akibat musnahnya barang yang dipersewakan ditanggung seluruhnya oleh pihak yang menyewakan. Ketentuan ini sungguh sebuah peraturan risiko yang sudah tepat, hal ini sudah sesuai dengan asas yang mengatakan "setiap pemlik barang wajib menanggung semua risiko atas barang miliknya." 16

Jika dilihat dari sudut pandang risiko, maka perjanjian sewa lahan (sewamenyewa) bukan merupakan hubungan hukum yang tepat bila dipakai dalam perjanjian perparkiran. Hal ini dikarenakan dalam perjanjian sewa-menyewa, risiko hanya mengenai objek sewa, di mana kalau digunakan dalam konteks perjanjian parkir, maka objek sewa lahan di mana diparkirnya kendaraan, yaitu tanah ukuran beberapa meter. Permasalahan akan timbul jika yang musnah adalah kendaraan yang diparkir di atas objek sewa (tanah lahan parkir). Kemudian mulai muncullah konsep menggunakan klausula baku atau intervensi Perda yang diwujudkan dalam karcis parkir, yang tentunya menganut perjanjian sewa-menyewa. Dengan dasar bahwa Pasal 1553 KUHPerdata akan menciptakan keadaan batal demi hukum,

\footnotetext{
${ }^{13}$ Subekti, Aneka Perjanjian, 43

14 Gardivega, Keberlakuan Perjanjian Sebagai Penitipan Sebagai Perjanjian Sah Dalam Kegiatan Peenyelenggaran Parkir Dikaitkan Dengan Asas Perbuatan Melawan Hukum Oleh Pengelola Parkir, 31

${ }^{15}$ Subekti, Aneka Perjanjian, 44

${ }^{16}$ Ibid
} 
maka pihak pengelola parkir akan dianggap tidak bertanggung jawab atas segala risiko yang timbul kemudian.

\section{Perjanjian Sewa Lahan (Sewa-Menyewa) Tidak Tepat Diterapkan Dalam Perjanjian Parkir}

Melihat karakteristik perjanjian sewa-menyewa, maka secara konseptual jika diterapkan dalam perjanjian parkir adalah perihal yang tidak tepat, karena dalam perjanjian sewa lahan (sewa-menyewa) adalah perjanjian yang melahirkan hak dan kewajiban pada masing-masing pihak. Sementara dalam perjanjian parkir menganut perjanjian sepihak karena hanya melahirkan hak pada satu pihak dan melahirkan kewajiban pada pihak lainnya. Kemudian dari pada itu, yang menjadi kewajiban dari pemberi sewa dalam perjanjian sewa-menyewa, sebagaimana diatur Pasal 1556, yaitu memberikan nikmat tenteram dari barang yang disewakan selama berlangsungnya waktu sewaan. Melihat karakteristik itu, maka seharusnya barang, baik bergerak atau tidak bergerak, adalah barang yang dapat dinikmati. Sementara dalam perjanjian parkir yang di sewa adalah lahan berapa meter sebagai tempat menaruh kendaraan, jadi tidak ada suatu apapun yang bisa dinikmati.

Selain itu, dari aspek risiko sebagaimana diatur dalam Pasal 1553 KUHPerdata, yang menjadi risiko pemberi sewa adalah barang yang menjadi obyek sewa, sementara yang menjadi obyek sewa adalah lahan atau tanah yang tidak akan bisa hilang, sehingga tidak ada risiko dari pemberi sewa, yang sering menjadi masalah adalah barang yang terdapat di atas obyek sewa, yaitu kendaraan. Sehingga sebenarnya kalau mengacu kepada perjanjian sewa-menyewa murni maka tidak ada tanggung jawab dari pemberi sewa terhadap obyek sewa. Dalam prakteknya terdapat karcis yang menyatakan kehilangan menjadi tanggung jawab pemilik kendaraan, kalau dalam perjanjian sewa-menyewa murni maka klausul ini tidak perlu dicantumkan. Oleh karenanya, sebenarnya secara diam-diam dalam perjanjian parkir, dalam prakteknya, tidak menggunakan dasar perjanjian sewamenyewa.

Persoalan yang tersisa selanjutnya dalam perjanjian parkir, mengenai dasar hukum yang harus dipakai, apakah yang dipatuhi adalah Peraturan Daerah atau Yurisprudensi. Melihat dua-duanya mempunyai dasar hukum yang sama kuat. Kalau melihat hirarki peraturan perundang-undangan, jika yang terjadi benturan norma (conflict of norm) antara Undang-Undang dengan Perda maka kita bisa menggunakan asas hukum "lex superirori derogate legi imperiori" artinya ketentuan hukum yang lebih tinggi mengalahkan ketentuan hukum yang lebih rendah". Jadi berdasarkan ketentuan asas tersebut tentu saja Undang-Undang dimenangkan dan mengeyampingkan peraturan daerah. Namun dalam kasus ini, apakah perda lebih tinggi daripada yurisprudensi mahkamah agung,

Berkaitan dengan hal ini, Mahkamah Agung telah beberapa kali memutuskan perkara tentang Parkir antara Anny R Gultom (konsumen/penggugat) Vs PT. Securindo Packtama/Secure Parking (pelaku usaha/tergugat) dalam Putusan MA No. $1264 \mathrm{~K} / \mathrm{Pdt} / 2003$ yang kemudian dikuatkan melalui Putusan Peninjauan Kembali No. 37/PDT/2007. Di mana mobil konsumen atau penggugat hilang di area parkir yang dikelola oleh Secure Parking. Dalam pertimbangannya Majelis Hakim Pengadilan Negeri menyatakan bahwa akibat kelalaian dan kekuarang hatihatian Tergugat serta sikap/perbuatan pasif dari Tergugat dengan tidak melakukan upaya maksimal untuk mencari dan mencegah keluarnya mobil Penggugat dapat 
dikualifikasikan sebagai perbuatan melawan hukum, juga melanggar asas kepatutan, ketelitian, dan kehati-hatian.

Point yang menjadi perhatian Mahkamah Agung dalam perkara ini juga yaitu terkait dengan pencantuman Klausula Baku. Klausula baku yang dimaksud adalah sebagaimana yang tertera di depan pintu masuk area parkir maupun dalam karcis parkir yang menyatakan: "Pihak Pengelola (parkir) tudak bertanggung jawab atas segala kehilangan, kerusakan, kecelakaan atas kendaraan atau kehilangan barangbarang yang terdapat di dalam kendaraan dan/atau yang menimpa orang yang menggunakan area parkir pihak pengelola (parkir)."

Mahkamah Agung menyatakan pada hakekatnya klausul tersebut merupakan perjanjian yang kesepakatanya bercacad hukum karena timbul dari ketidakbebasan pihak yang menerima klausul. Sebab manakala pengendara mobil memasuki area parkir, ia tidak punya pilihan lain selain memilih parkir di areal parkir tersebut sehingga dapat diterima seolah-olah dalam keadaan terpaksa oleh pihak pengendara. Sehingga Mahkamah Agung memutuskan bahwa pengelola parkir harus memberikan ganti rugi terhadap kehilangan kendaraan konsumen.

Selain itu putusan Mahkamah Agung terkait dengan Parkir yaitu Putusan No. 2078 K/PDT/2009 perkara antara PT. Securindo Packtama Indonesia/Secure Parking (Pelaku Usaha/tergugat/pemohon kasasi) Vs. Sumito Y Viansyah (konsumen/penggugat/termohon kasasi). Yang mana konsumen/penggugat/termohon kasasi kehilangan sepeda motor di area parkir dari pelaku usaha/tergugat/pemohon kasasi. Kemudian pelaku usaha menolak untuk bertanggung jawab dengan alasan sudah sesuai dengan Pasal 36 ayat (2) Perda No. 5 tahun 1999, yang menyatakan bahwa kehialangan merupakan tanggung jawab pemakai tempat parkir.

Terhadap pandangan pelaku usaha tersebut di atas bahwa majelis hakim tidak sependapat dengan dalil Tergugat. Hal tersebut didasarkan pada pertimbangan hukum ketentuan yang termuat dalam Perda tersebut bertentangan dengan aturan hukum yang lebih tinggi yaitu KUHPerdata dan UU Perlindungan Konsumen, khususnya Pasal 18, yang melarang secara tegas bagi pelaku usaha untuk menerapkan klausula baku dalam dokumen maupun perjanjian, yang mempunyai akibat hukum dinyatakan batal demi hukum. Selain dari pada itu, Mahkamah Agung membenarkan putusan judex facti yang mendasarkan putusan dengan pertimbangan bahwa hubungan hukum antara pemilik kendaraan dengan pengusaha parkir merupakan "perjanjian penitipan barang", yang jika dihubungkan dengan Pasal 1365, 1366, dan 1367 KUHPerdata, maka pengelola parkir menanggung kehilangan sepeda motor konsumen hilang di tempat area parkir yang dikelolanya. ${ }^{17}$

Oleh karenanya dalam mengkonstruksi sebuah perda yang mempunyai tingkat validitas yang tinggi, maka tentu harus berdasar pada sumber-sumber hukum yang ada. Dalam Ilmu Hukum dikenal ada beberapa sumber hukum yaitu Undang-undang, yurisprudensi, kebiasaan, traktat, pendapat ahli hukum (Doktrin). Sehingga kalau dipertanyakan dari mana lahirnya perda perparkiran yang menganut sistem perjajian sewa lahan (sewa-menyewa) maka ini bertentangan dengan sumber hukum yaitu yurisprudensi yang mana mayoritas putusan-putusan

17 Putusan Mahkamah Agung No. 2078 K/Pdt/2009, 38, baca juga Ahmad Fikri Assegaf, Penjelasan Hukum Tentang Klausula Baku, (Jakarat: PSHK, 2014), 209 
Mahkamah Agung menyatakan bahwa perjanjian parkir adalah perjanjian penitipan barang. Berdasarkan hal tersebut dapat disimpulkan bahwa hubungan hukum antara konsumen pemilik kendaraan dengan pengelola parkir yaitu hubungan hukum perjanjian penitipan barang.

\section{Tanggung Jawab Pelaku Usaha Parkir Terhadap Barang yang Terdapat di Dalam Kendaraan Konsumen}

Pemahaman perjanjian parkir dipahami sebagai perjanjian penitipan barang. Hal tersebut berdasarkan pada Putusan Mahkamah Agung No. $2078 \mathrm{~K} / \mathrm{Pdt} / 2009^{18}$ dan Putusan Peninjauan Kembali Perkara Nomor: 124/PDT/2007 yang dilayangkan oleh PT. Securindo Packatama Indonesia (SPI) sebagai pengelola jasa parkir atas putusan kasasi yang memberikan kemenangan konsumennya, di mana konsumen dimenangkan atas putusan ganti kerugian. Putusan tersebut memaksa PT. SPI untuk memberikan ganti kerugian akibat dari kehilangan kendaraan di area parkir yang dikelolanya. Karena ini adalah putusan Mahkamah Agung, maka hal tersebut berlaku sebagai yurisprudensi, artinya harus diikuti oleh semua pengelola parkir di seantero Indonesia, karena yurisprudensi merupakan salah satu sumber hukum.

Apa konsekuensi hukum apabila hubungan hukum pengelola parkir dan konsumen pemilik kendaraan adalah perjanjian penitipan barang, tentu perjanjian ini diikat oleh ketentuan-ketentuan perjanjian penitipan barang sebagaimana diatur dalam KUHPerdata. Perjanjian antara pengelola parkir dengan konsumen pemilik kendaraan tidak seperti halnya perjanjian yang dibuat pada umumnya, yang memuat berlembar-lembar hak dan kewajiban para pihak. Dalam prakteknya perjanjian parkir itu diwujudkan dalam bentuk karcis parkir. Dalam karcis parkir itulah tertuang hak dan kewajiban dari masing-masing pihak, biasanya ini dibuat dalam perjanjian baku (Standart Contract). ${ }^{19}$

Menurut Pasal 1233 KUHPerdata, terdapat dua penyebab yang menimbulkan perikatan yaitu perjanjian dan undang-undang. Pada prinsipnya perikatan itu mengandung tiga jenis prestasi yaitu memberi sesuatu, berbuat sesuatu, dan tidak berbuat sesuatu (Pasal 1234 KUHPerdata). Dari ketiga jenis prestasi di atas, dapat dikatakan bahwa perjanjian penitipan barang merupakan perjanjian untuk berbuat sesuatu. Menurut Pasal 1694 KUHPerdata: "Penitipan adalah terjadi menerima sesuatu barang dari seorang lain, dengan syarat bahwa ia akan menyimpannya dan mengembalikannya dalam wujud asal."

Dari definisi di atas bahwa perjanjian penitipan barang adalah perjanjian riil, di mana ia terjadi apabila telah terjadi perbuatan nyata, yaitu diserahkannya barang yang dititipkan, tidak seperti perjanjian-perjanjian umum lainnya yang lazim yaitu konsensual, yaitu lahir pada saat tercapainya kata sepakat tentang hal-hal yang pokok dari perjanjian itu. ${ }^{20}$ Penitipan barang dalam KUHPerdata dibagi menjadi dua yaitu penitipan barang sejati dan penitipan sekestrasi. Perjanjian parkir ini merupakan bagian dari perjanjian penitipan barang sejati. ${ }^{21}$ Menurut Pasal 1696

\footnotetext{
${ }^{18}$ Putusan Mahkamah Agung No. 2078 K/Pdt/2009, 38

19 Taufik Yahya dkk, "Perlindungan Konsumen Atas Klausula Eksonarasi Dalam Perjanjian Jasa Perparkiran di Kota Jambi”, Majalah Forum Akademika, 25 (1), 27.

${ }^{20}$ Subekti, Aneka Perjanjian, Op.Cit, 107-108

${ }^{21}$ Taufik Yahya dkk, Perlindungan Konsumen atas Klausula Eksonerasi dalam Perjanjian Jasa Perparkiran di Kota Jambi, 37.
} 
KUHPerdata, Penitipan barang sejati adalah dibuat cuma-cuma, jika tidak diperjanjikan sebaliknya, sedangkan ia hanya dapat mengenai barang-barang yang bergerak. Sedangkan Penitipan barang skestrasi adalah penitipan barang tentang di mana ada perselisihan, di tangannya seorang pihak ketiga yang mengikatkan diri untuk, setelah perselisihan itu diputus, mengembalikan barang itu kepada siapa yang akan dinyatakan berhak, beserta hasil-hasilnya. Penitipan ini ada yang terjadi dengan kesepakatan dan ada juga yang dilakukan atas perintah hakim atau pengadilan, sebagaimana yang diatur dalam Pasal 1730 KUHPerdata.

Dalam KUHPerdata Pasal 1698 dikatakan bahwa penitipan barang dapat terjadi karena dua hal yaitu dengan sukarela atau karena terpaksa. Dalam Pasal 1699 dijelaskan bahwa Penitipan sukarela terjadi karena kesepakatan timbal-balik antara pihak yang menitipkan barang dan pihak yang menerima titipan. Penitipan barang secara sukarela hanya dapat terjadi antara orang-orang yang mempunyai kecakapan untuk membuat perjanjian-perjanjian. Namun, jika seseorang yang cakap membuat perjanjian menerima penitipan suatu barang dari orang yang tidak cakap membuat suatu perjanjian, maka si penerima titipan harus tunduk pada kewajiban yang dipikul oleh orang yang menerima titipan secara sungguhsungguh. ${ }^{22}$ Perjanjian parkir dapat dikategorikan ke dalam perjanjian penitipan barang sejati, karena objeknya adalah benda bergerak, yaitu kendaraan. Sebagai perbandingan, dalam hukum Islam perjanjian penitipan barang disebut dengan Wadi'ah. Artinya adalah titipan murni dari satu pihak ke pihak lain, baik individu maupun badan hukum, di mana barang yang dititip tersebut harus dijaga dan dikembalikan ketika si penitip menghendakinya. ${ }^{23}$ Dari beberapa pendapat mayoritas ulama dapat diambil benang merang bahwa istilah Wadi'ah berarti suatu akad antara dua orang atau lebih, di mana pertama menyerahkan tugas dan wewenang untuk menjaga barang yang dimilikinya kepada pihak lain. Objek yang diserahkan tersebut merupakan amanah yang harus dijaga dengan baik.

Adapun rukun dari Wadi'ah terdapat pendapat para ulama yaitu menurut Hanafiah bahwa hanya satu rukun Wadi'ah yaitu ijab dan qabul. Namun pendapat mayoritas ulama menyebutkan ada empat rukun wadi'ah yaitu; pertama, orang yang menitipkan (al-maudi'). Kedua, orang yang dititipi (al-wadi'). Ketiga, shigat dan keempat adalah benda yang dititipkan (al-'ain al-muda'ah). Syarat wadi'ah terkait dengan 4 rukun di atas, di mana dua syarat yang pertama adalah syarat subyektif dari sebuah wadi'ah. Di mana di syaratkan bahwa subyek atau orang yang memberi titipan atau menerima titipan harus memenuhi kriteria yaitu, harus berakal, baligh, dan diduga kuat mampu menjaga barang yang dititipkan kepadanya. Kemdian syarat ketiga yaitu Shigat adalah ijab dan qabul. Syarat shigat harus dinyatakan dengan ucapan atau perbuatan. Syarat terakhir adalah benda yang dititipkan. Persyaratan benda yang dititipkan harus mempunyai dua ketentuan yaitu; Pertama, benda yang dititipkan adalah benda yang bisa disimpan. Apabila benda tersebut tidak bisa disimpan, maka wadi'ah teresebut tidak syah, konsekuensinya apabila hilang tidak wajib diganti. Kedua, benda yang dititipkan harus mempunyai nilai (qimah) dan dipandang sebagai mal, walaupun najis. Seperti anjing yang bisa difungsikan sebagai hewan pemburu atau penjaga keamanan. Apabila benda tersebut tidak mempunyai nilai, seperti anjing yang tidak

\footnotetext{
${ }^{22}$ Subekti, Aneka Perjanjian, 108.

${ }^{23}$ Muhammad Syafi'i Antonio, Bank Syari'ah Dari Teori Ke Praktek, (Jakarta, Amzah, 2014), 455.
} 
bisa difungsikan, maka wad'iah tidak sah. ${ }^{24}$ Melihat konsep perjanjian penitipan barang dalam KUHPerdata dan Hukum Islam hampir mirip termasuk dalam syarat-syarat sahnya perjanjian penitipan barang. Namun terdapat sedikit perbedaan di mana dalam KUHPerdata meskipun seorang penitip adalah orang yang tidak cakap, si penerima titipan tetap harus tunduk pada kewajiban yang dipikul oleh yang menerima titipan secara sungguh-sungguh.

Dalam perjanjian parkir lazimnya yang dititip oleh pihak penitip adalah kendaraan, baik roda dua atau roda empat (mobil) kepada pengelola parkir. Karena perjanjian parkir dikategorikan sebagai perjanjian penitipan barang berdasarkan unsur-unsurnya, dan berdasarkan yurisprudensi Mahkamah Agung, maka pengaturannya tunduk pada perjanjian penitipan barang sebagaimana diatur dalam KUHPerdata. Perjanjian penitipan barang terdapat pengaturan mengenai hak dan kewajiban dari para pihak, penerima titipan dan pemberi titipan. Pasal 1706 KUHPerdata menentukan kewajiban memelihara benda yang dititip oleh pihak yang diberi titipan yaitu: (1) Si Penerima titipan diwajibkan untuk melakukan perawatan barang yang dipercayakan padanya; (2) Memelihara dengan kepedulian yang sama seperti ia memelihara atau merawat barang-barangnya sendiri.

Ketentuan dalam klausul pasal tersebut menjelaskan bahwa kewajiban dari penerima titipan adalah memelihara dan merawat barang yang dititipkan kepadanya. Perawatan terhadap barang yang dititipkan kepadanya seolah-olah merawat barang miliknya sendiri. Artinya dalam konteks perjanjian parkir, maka pihak pengelola parkir memiliki kewajiban memelihara kendaraan sebagaimana memelihara kendaraannya, seperti menjaganya dari gangguan orang lain yang menimbulkan kecacatan atau kehilangan yang bisa merubah wujud objek tersebut berubah dari wujud semula. Sehingga jika terjadi kehilangan kendaraan yang dimiliki oleh si pemberi titipan, maka pihak pengelola parkir, sebagai penerima titipan, bertanggung jawab terhadap kehilangan kendaraan si pemberi titipan, dalam hal ini adalah konsumen. Kewajiban tersebut tertuang dengan cukup jelas dalam definisi penitipan barang dalam Pasal 1694, di mana si penerima titipan akan menyimpan dan mengembalikan dalam wujud asal barang yang dititipkan tersebut. Jika terjadi kehilangan atau terjadi perubahan wujud dari objek yang dititipkan, maka si penerima titipan harus mengembalikan dalam wujud asalnya. Artinya jika kendaraan konsumen (pemberi titipan) hilang, maka pengelola parkir (penerima titipan) harus mengembalikan barang sebagaimana mestinya.

Kaidah hukum perdata bisa dikatakan mirip dengan hukum Islam dalam hal tanggung jawab penerima titipan terhadap objek penitipan. Dikatakan bahwa orang yang dititipi hendaknya menjaga titipan itu sebagaimana ia menjaga harta miliknya sendiri, hal itulah yang diungkapkan oleh ulama penganut Mazhab Hanafi dan Hambali. Lebih ketat lagi tanggung jawab penerima titipan menurut ajaran Mazhab Syafi'i di mana si penerima titipan harus menjaga sendiri barang titipan tersebut, bahkan tidak boleh menjaganya di tempat isteri atau anak, kecuali tanpa izin dari pemberi titipan atau alasan uzur. Jika si penerima titipan menyalahi cara penjagaan terhadap barang yang dititipkan, maka dia harus bertanggung jawab untuk mengganti barang titipan tersebut jika terjadi terdapat perubahan keadaanya

\footnotetext{
${ }^{24}$ Ahmad Wardi Muslich, Fiqih Muamalat, (Jakarta, Amzah, 2013), 461
} 
atau terdapat kehilangan. Dia dibebaskan dari tanggung jawab, apabila terdapat uzur seperti sakit.

Bagaimana dengan perda DKI Jakarta Nomor 5 Tahun 1999 tentang Perparkiran di mana ketentuan Pasal 36 ayat (2) yang pada intinya mengatur tentang kehilangan kendaraan menjadi tanggung jawab konsumen sendiri (pemberi titipan). Ketentuan tersebut bertentangan dengan konsep perjanjian penitipan barang yang di mana harus mengembalikan wujud asal objek yang dititipkan. Hal yang sama juga terlihat dalam Perda Kota Mataram No. 7 Tahun 2015 tentang Pengelolaan Parkir Pasal 13 ayat (1) dan (2), yang pada intinya mengatur ketentuan ganti rugi ditanggung oleh kedua belah pihak dengan presentase 50:50. Hal ini juga tidak sesuai dengan konsep penitipan barang, di mana perjanjian penitipan barang yang membebankan kewajiban kepada pihak pengelola (penerima titipan) untuk memberikan ganti rugi atau mengembalikan wujud asal objek yang dititipkan, jika masa penitipan sudah usai (Pasal 1694 KUHPerdata). Sehingga sebuah kekeliruan dalam menyusun sebuah perda dengan tidak memperhatikan konsep dasar hubungan hukumnya, yaitu perjanjian penitipan barang. Karena syarat pengelola parkir, sebagai pihak penerima titipan bertanggung jawab terhadap kehilangan objek yang dititipkan, dalam konteks perparkiran yaitu kendaraan konsumen. Jika kerugiannya dibagi, maka tentu ini menyalahi konsep perjanjian penitipan barang sebagaimana diatur dalam Pasal 1694 KUHPerdata.

Sudah cukup jelas jika konsumen (pemberi titipan) kehilangan kendaraannya menjadi tanggung jawab mutlak pengelola parkir sebagai penerima titipan kendaraan jika terjadi kehilangan. Namun yang masih terdapat kekaburan norma (unclear norm) dan menjadi perdebatan para ahli yaitu bagaimana jika kehilangan tersebut adalah barang yang terdapat di dalam kendaraan. Apakah ini menjadi tanggung jawab pengelola parkir, sebagai penerima titipan atau menjadi tanggung jawab konsumen, sebagai pemberi titipan. Seperti dalam Perda Kota Denpasar No. 11 Tahun 2005 tentang Penyelenggaran Perparkiran dalam Pasal 11 sampai dengan Pasal 13 mengenai santunan kehilangan kendaraan, tercantum bahwa konsumen pengguna jasa parkir mendapat ganti kerugian dari kehilangan kendaraan konsumen. Akan tetapi hanya kendaraan yang hilang secara utuh yang mendapat ganti kerugian. Ketika konsumen kehilangan tidak utuh seperti helm, handphone, bahkan kehilangan kendaraan karena kunci masih ada dikendaraan tidak mendapat ganti kerugian. ${ }^{25}$

Maka tentu perjanjian parkir ini tunduk pada hak dan kewajiban dalam perjanjian penitipan. Adapun hak dan kewajiban dalam perjanjian penitipan diatur dalam Pasal 1706 KUHPerdata yang mana menentukan kewajiban memelihara benda yang dititip oleh pihak yang diberi titipan, dengan cara memelihara seperti barang kepunyaan sendiri. Jika melihat isi Pasal 1706 tersebut dan dihubungkan dengan perjanjian perparkiran bahwa tanggung jawab pengelola parkir adalah memelihara barang titipan itu sebaik-baiknya seperti memelihara barang-barang kepunyaan sendiri dan mengembalikan seperti keadaan sediakala pada waktu awal dititipkan. Artinya, kewajiban pengelola parkir adalah menyerahkan barang titipan kepada penitip, menjaga dan memelihara barang titipan sepanjang waktu

\footnotetext{
${ }^{25}$ Ida Bagus Wahyu Prakosa Wiguna dkk, "Perlindungan Hukum Konsumen Jasa Parkir Dalam Hal Terjadinya Kehilangan Helm dan Kendaraan Bermotor di Pasar Kreneng Denpasar", Jurnal Komunitas Yustisia Universitas Pendidikan Ganesha, 1 (2), 6
} 
penitipan. ${ }^{26}$ Dari sisi fasilitas dalam kebiasaan perjanjian perparkiran, pengelola parkir bisa memberikan pembuktian jika terjadi kehilangan barang yang dititipkan. Seperti kamera CCTV atau dari kesaksian petugas parkir yang ditugaskan untuk menjaga kendaraan. Hal tersebut sebagai wujud pelaksanaan perawatan dan pemeliharaan barang-barang sebagaimana diwajibkan dalam Pasal 1706 KUHPerdata tersebut.

Ketentuan lebih lanjut mengenai pemberatan tanggung jawab penerima titipan jika penitipan barang itu ditawarkan atau diperjanjikan, sebagaimana tertuang dalam Pasal 1707 KUHPerdata yang menyatakan bahwa; Ketentuan Pasal yang lalu harus dilakukan lebih keras: (1) Jika si penerima titipan telah menawarkan dirinya untuk menyimpan barangnya; (2) Jika ia telah meminta diperjanjikannya suatu upah untuk menyimpan itu; (3) Jika penitipan itu telah terjadi sedikit banyak untuk kepentingan si penerima titipan; (4) Jika telah diperjanjian bahwa si penerima titipan akan menanggung segala macam kelalaian. Pasal tersebut dengan sangat jelas memberikan makna bahwa penitipan kendaraan yang biasa disebut dengan jasa parkir telah memenuhi unsur-unsur Pasal 1707 tersebut. Dalam perjanjian parkir, pengelola parkir menawarkan jasanya untuk menyimpan atau memelihara barang (kendaraan) dalam waktu tertentu, dan perjanjian itu mendapatkan upah. Sehingga tanggung jawab pengelola parkir semakin berat, seperti menjaga dan memelihara seperti kepunyaan barang sendiri. Beberapa tanggung jawab penerima titipan juga disebutkan dalam KUHPerdata seperti yang dituangkan dalam Pasal 1709 dan Pasal 1710 yang menyatakan bahwa:

"orang-orang yang menyelenggarakan rumah penginapan dan penguasapenguasa losmen adalah sebagai orang-orang yang menerima titipan barang, bertanggung jawab untuk barang-barang yang dibawa oleh para tamu yang menginap pada mereka. Penitipan barang yang itu dianggap sebagai suatu penitipan barang karena terpaksa."

"Mereka adalah bertanggung jawab tentang pencurian atau kerusakan pada barang-barang kepunyaan para penginap, baik pencurian itu dilakukan atau kerusakan itu diterbitkan oleh pelayan-pelayan atau lain-lain budak dari rumah penginapan, maupun oleh setiap orang lain".

Jika dihubungkan tanggung jawab pengelola parkir seperti penitipan pada penyelenggara rumah penginapan. Dalam keadaan tersebut, si penerima titipan bertanggung jawab tentang pencurian atau kerusakan barang pada barang-barang kepunyaan penginap, baik pencurian itu dilakukan atau kerusakan itu dilakukan oleh pelayan-pelayan atau orang lain yang ada di rumah penginapan tersebut. ${ }^{27}$ Untuk menganalogikan tersebut pada penitipan kendaraan maka dapat identifikasi unsur-unsurnya yaitu: 1) Penitipan kendaraan adalah penitipan sejati; 2) Pihak pemberi titipan dan penerima titipan adalah pihak yang cakap. Dibuktikan bahwa pengendara telah dewasa dan memiliki surat izin mengemudi sebagai tanda kecakapannya, begitu juga pihak penerima titipan adalah pihak yang cakap karena pihak tersebut merupakan subjek hukum dalam bentuk badan hukum tertentu; 3) Dalam perjanjian penitipan barang ditetapkan suatu upah untuk jasa penitipan

\footnotetext{
${ }^{26} \mathrm{Ibid}, 8$

${ }^{27}$ Taufik Yahya, 38
} 
barang. Dalam penelitian ini upah ditentukan oleh pihak parkir dengan mengacu ketentuan yang ditetapkan oleh pemerintah dan swasta berdasarkan waktu parker; 4) Penitipan kendaraan yang semakin tinggi menyebabkan keuntungan yang tinggi pula diterima oleh pengusaha penitipan kendaraan; 5) Pada akhirnya penitipan tersebut, mengenai objeknya menjadi tanggung jawab pihak penerima titipan. ${ }^{28}$

Dengan melihat tanggug jawab penitipan barang dan identifikasi tersebut di atas, maka kewajiban dari pihak penerima titipan adalah menjaga objek penitipan beserta barang-barang yang terdapat di dalamnya, baik dari kerusakan ataupun kehilangan. Oleh karena itu, jika terjadi kerusakan atau kehilangan benda yang terdapat di dalam kendaraan yang dititip, maka yang bertanggung jawab adalah tetap pihak penerima titipan. Dengan demikian dalam perjanjian parkir, pihak pengelola parkir bertanggung terhadap kendaraan dan semua objek yang terdapat di dalam kendaraan tersebut, karena pengelola parkir sebagai pihak penerima parkir bertanggung jawab menjaga barang-barang pemberi titipan dari pencurian atau kerusakan yang diakibatkan oleh karyawannya. Oleh karenanya, peyelenggaraan pengelolaan parkir bukanlah perkara yang mudah dan tidak berisiko, tapi sebaliknya karena perjanjian melahirkan hak dan kewajiban yang seimbang berdasarkan pada keuntungan yang didapatkan.

Ketentuan Undang-Undang No. 8 Tahun 1999 tentang Perlindungan Konsumen, Pasal 3 huruf (e) mengatakan bahwa tujuan dari perlindungan konsumen salah satunya adalah meningkatkan kesadaran pelaku usaha mengenai pentingnya perlindungan konsumen sehingga tumbuh sikap yang jujur dan bertanggung jawab dalam berusaha. Pasal ini memberikan pesan bahwa pelaku usaha harus jujur dan bertanggung jawab terhadap hak dan kewajibannya. Dalam praktek perjanjian perparkiran, untuk melakukan pencegahan terhadap kerugian yang dialami oleh konsumen, pengelola parkir melakukan pemasangan kamera CCTV, kemudian menugaskan karyawan untuk melakukan keliling setiap beberapa waktu untuk memastikan kendaraan aman dari gangguan atau kerusakan. Selain itu, dalam praktek juga terdapat klausul perjanjian baku bahwa barang-barang berharga mohon dibawa. Jika ingin membuat sebuah pencegahan sehingga kehilangan barang berharga di dalam kendaraan konsumen tidak menjadi tanggung jawab dari pengelola parkir maka, sebaiknya harus ditentukan bahwa setiap konsumen yang mempunyai barang berharga di dalam kendaraannya harus dilaporkan sehingga ini memudahkan pembuktian, sehingga pertanggungjawabannya juga jelas sesuai dengan fakta atau bukti laporan konsumen. Selain itu, konsumen tidak berpotensi melakukan itikad tidak baik untuk memperoleh keuntungan. Dalam Pasal 5 huruf (b) Undang-Undang Perlindungan Konsumen mengatakan bahwa kewajiban konsumen adalah beritikad baik dalam melakukan transaksi pembelian barang dan/atau jasa. Artinya bahwa konsumen juga harus melaksanakan transaksinya dengan itikad baik, demikian juga sebaliknya.

Dalam Pasal 8 huruf (a) Undang-Undang Perlindungan Konsumen yang mengatur tentang perbuatan yang dilarang bagi pelaku usaha bahwa pelaku usaha dilarang memproduksi dan/atau memperdagangkan barang dan/atau jasa yang tidak memenuhi atau tidak sesuai dengan yang dipersyaratkan dan ketentuan peraturan perundang-undangan. Sehingga dengan demikian, jika perjanjian parkir 
adalah perjanjian penitipan barang maka syarat dan ketentuan perjanjian tersebut tunduk pada ketentuan perjanjian penitipan barang yang diatur dalam KUHPerdata. Dalam perjanjian penitipan barang, menentukan bahwa kewajiban penerima titipan adalah memelihara barang seperti kepunyaannya sendiri dan mengembalikan barang titipan dalam wujud semula setelah perjanjian penitipan tersebut selesai. Artinya bahwa standar perjanjian parkir adalah pengembalian kendaraan dalam wujud semula jika perjanjian sudah usai, jika tidak, misalnya karena kehilangan atau kerusakan maka hal tersebut menjadi tanggung jawab pengelola parkir. Bagaimana dengan barang yang ada dalam kendaraan, jika tidak ada yang mengatur mengenai sejauh mana tanggung jawab pelaku usaha parkir terhadap barang yang teradapat dalam kendaraan. Maka, hal tersebut menjadi tanggung jawab pengelola parkir.

\section{Kesimpulan}

Hubungan hukum antara pelaku usaha parkir dengan konsumen pemilik kendaraan bukanlah hubungan perjanjian sewa lahan (sewa-menyewa) karena unsur-unsur dalam perjanjian sewa-menyewa tidak sesuai jika diterapkan dalam perjanjian parkir karena dalam perjanjian sewa-menyewa hanya melahirkan hak di satu pihak dan kewajiban di pihak lain atau tidak melahirkan hak dan kewajiban di masing-masing pihak, tetapi hubungan hukum pelaku usaha parkir dengan konsumen adalah perjanjian penitipan barang sebagaimana diatur dalam Pasal 1694 KUHPerdata. Hal ini didasarkan pada yurisprudensi Mahkamah Agung No. $2078 \mathrm{~K} / \mathrm{Pdt} / 2009$. Sehingga pengaturan mengenai hak dan tanggung jawab dalam perjanjian parkir tunduk pada perjanjian penitipan barang. Konsep peraturan daerah yang mengatur tentang perparkiran yang membebankan tanggung jawab kehilangan kendaraan pada konsumen, menyalahi konsep perjanjian penitipan barang. Karena perjanjian parkir melahirkan hak dan kewajiban pada masingmasing pihak.

Tanggung jawab pelaku usaha parkir terhadap kehilangan barang yang terdapat di dalam kendaraan konsumen yaitu menjadi tanggung jawab pengelola parkir, karena tanggung jawab pengelola parkir sebagai pihak penerima titipan adalah memelihara obyek titipan sebagaimana memelihara kepunyaan sendiri serta harus mengembalikan dalam wujud asalnya. Sehingga kehilangan barang yang terdapat di dalam kendaraan konsumen tetap menjadi tanggung jawab pengelola parkir.

\section{Daftar Pustaka}

Abdullah Halim Barkatullah, Hukum Perlindungan Konsumen; Kajian Teoritis Dan Perkembangan Pemikiran, Banjarmasin: Unlam Press, 2008.

Adami Chazawi, Pelajaran Hukum Pidana Bagian I, Jakarta: Rajawali Pers, 2005. , Pelajaran Hukum Pidana Bagian II, Jakarta: Rajawali Pers, 2002.

Adrian Sutedi, Tanggung Jawab Produk Dalam Hukum Perlindungan Konsumen, Bogor: Ghalia Indonesia, 2008.

Ahmad Fikri Assegaf, Penjelasan Hukum Tentang Klausula Baku, Jakarat: PSHK, 2014. 
Ahamdi Miru dan Sutarman Yodo, Hukum Perlindungan Konsumen, Jakarta: Rajawali Pers, 2004.

Ahmad Wardi Muslich, Fiqih Muamalat, Jakarta, AmzaH, 2013.

Ahmad Zuhairi, Konstruksi Perlindungan Hukum Bagi Pengadu/Pelapor Kerugian Konsumen Dari Tuntutan Pencemaran Nama Baik, Jurnal Ius Kajian Hukum dan Keadilan, Vol. III No. 1 http://dx.doi.org/10.12345/ius.v3i7.199

A. Sony Keraf,Etika Bisnis; Tuntutan Dan Relevansinya, Yogyakarta: Penerbit Kanisius, 1998.

Deviana Yuanitasari dan Hazar Kusmayanti, Eksistensi BPSK (Badan Penyelesaian Sengketa Konsumen) Dalam Pengawasan Pencantuman Klausula Baku Dalam Sistem Hukum Perlindungan Konsumen Indonesia, Jurnal IUS Kajian Hukum dan Keadilan, Vol. VII No. 3, 427, http://dx.doi.org/10.29303/ius.v7i3.676

Dyah Octorina Susanti dan IGN Parikasit Widiatedja, Asas Keadilan; Konsep dan Implementasinya Dalam Perspektif Hukum Islam Dan Hukum Barat, Malang: Bayumedia Publishing, 2011.

Dominique Lauterbur, Food Law: Policy \& Ethics, London. Sydney: Cavendish Publishing Limited, 2001.

Edi Setiadi Dan Rena Yulia, Hukum Pidana Ekonomi, Yogyakarta: Graha Ilmu, 2010

Erman Rajagukguk, Butir-Butir Hukum Ekonomi, Jakarta: UI Press, 2011.

Husni Syawali Dan Neni Sri Imaniyati (Penyunting), Hukum Perlindungan Konsumen, Bandung: Mandar Maju, 2000

Ida Bagus Wahyu Prakosa Wiguna dkk, Perlindungan Hukum Konsumen Jasa Parkir Dalam Hal Terjadinya Kehilangan Helm dan Kendaraan Bermotor di Pasar Kreneng Denpasar, Jurnal Komunitas Yustisia Universitas Pendidikan Ganesha, Jurusan Ilmu Hukum, Vol. 1 No. 2, 2018

Janus Sidabalok, Hukum Perlindungan Konsumen Di Indonesia, Bandung: Citra Aditya Bhakti, 2006.

Jimly Ashiddiqe, Konstitusi Ekonomi, Jakarta: Kompas, 2010.

Jhony Ibrahim, Teori dan Metodologi Penelitian Hukum Normatif,Malang: Bayumedia, 2007.

Johanes Widijantoro, Mewujudkan Perniagaan Berkeadilan Melalui Peningkatan Keadilan Konsumen, Jurnal Mimbar Hukum, Vol. XXVIII No.3, https://doi.org/10.22146/jmh.16672

Muhammad Syafi'i Antonio, Bank Syari'ah Dari Teori Ke Praktek, Jakarta, Gema Insani, 2001.

Muhammad Yunus, Menciptakan Dunia Tanpa Kemiskinan, Jakarta: Gramedia,2008.

Muladi dan Dwidja Priyatno, Pertanggungjawaban Pidana Korporasi, Jakarta: Kencana, 2010.

Paulus Tomy Prihwaskito, Tinjauan Yuridis Perjanjian Sewa Menyewa Depo Container Yard PT. Kawasan Barikat Nusantara Persero (Studi Kasus Putusan MA No. 116/PK/Pdt/2015, Diponegoro Law Journal, Volume 5 No.4. 2016

Philipus M. Hadjon, Perlindungan Hukum Bagi Rakyat Indonesia; Sebuah Studi tentang Prinsip-Prinsipnya, Penanganannya oleh Pengadilan Dalam 
296 | De Jure: Jurnal Hukum dan Syar'iah, Vol. 12 No. 2 Tahun 2020

Lingkungan Perdilan Umum dan Pembentukan Peradilan Administrasi Negara, Surabaya: Bina Ilmu, 1985.

Rachmad Syafaat, Advokasi dan Alternatif Penyelesaian Sengketa, Malang: Surya Pena Gemilang, 2011.

R. Otje Salman S dan Anthon F Susanto, Teori Hukum, Rafika Aditama, Bandung: 2007.

Romli Atmasasmita, Pengantar Hukum Kejahatan Bisnis, Jakarta: Kencana, 2003.

Renaldo Oktavia Gardivega, Keberlakuan Perjanjian Sebagai Penitipan Sebagai Perjanjian Sah Dalam Kegiatan Peenyelenggaran Parkir Dikaitkan Dengan Asas Perbuatan Melawan Hukum Oleh Pengelola Parkir, Skripsi Fakultas Hukum Universitas Indonesia, 2011.

Shidarta dkk, Aspek Hukum Ekonomi dan Bisnis, Jakarta: Kencana, 2018

Sri Redjeki Hartono, Hukum Ekonomi Indonesia, Malang: Bayumedia,2007.

Subekti, R, Aneka Perjanjian, Bandung: PT.Aditya Bakti, 2014

Sukarmi, Cyber Law, Kontrak Elektronik dalam bayang-bayang pelaku usaha, Bandung: Pustaka Sutra, 2008.

Susanti Adi Nugroho, Proses Penyelesaian Sengketa Konsumen Ditinjau dari Hukum Acara Serta Kendala Implementasinya, Jakarta: Kencana, 2011.

Taufik Yahya Dkk, Perlindungan Konsumen Atas Klausula Eksonarasi Dalam Perjanjian Jasa Perparkiran di Kota Jambi, Majalah Forum Akademika, Volume 25 No.1, Maret 2014.

Teguh Prasetyo, Kriminalisasi Dalam Hukum Pidana, Bandung: Nusa Media, 2010.

Yusuf Shofie, Pelaku Usaha, Konsumen, Dan Tindak Pidana Korporasi ,Jakarta: Ghalia Indonesia, 2002.

, Perlindungan Konsumen Dan Instrumen-Instrumen Hukumnya, Bandung: Citra Aditya Bakti, 2003.

Zunnuraeni, Kewenangan Desa Dalam Pengelolaan Hutan Untuk Mitigasi Perubahan Iklim, Jurnal Ius Kajian Hukum dan Keadilan, Vol. VII No. 1, http://dx.doi.org/10.29303/ius.v6i1.524.

http://www.suarantb.com/news/2017/06/10/240048/Pencurian.Uang.Ratusan.J uta.di.Parkir.Mataram.Mall,Ini.Reaksi.Polisi

http://www.suarantb.com/news/2017/06/08/239984/Mobil.Mamiq.Dar,Tokoh. Berpengaruh.Asal.Sekotong.Dibobol,Ratusan.Juta.Digondol 